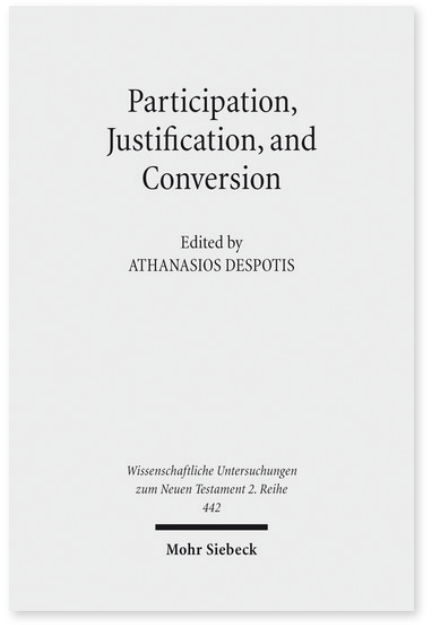

2017. X, 435 Seiten. WUNT II 442

ISBN 978-3-16-155453-7

DOI 10.1628/978-3-16-155453-7

BBook PDF $99,00 €$

ISBN 978-3-16-154140-7

fadengeheftete Broschur $99,00 €$

\section{Participation, Justification, and Conversion}

\author{
Eastern Orthodox Interpretation of Paul and the Debate between "Old and New \\ Perspectives on Paul« \\ Ed. by Athanasios Despotis
}

[Partizipation, Rechtfertigung und Bekehrung. Östlich-orthodoxe Interpretation des Paulus und die Debatte zwischen »alten und neuen Perspektiven auf Paulus".]

Veröffentlicht auf Englisch.

Die Debatte zwischen der »alten« und der »neuen Paulusperspektive« ist in den letzten Jahrzehnten zu einem Schwerpunkt der paulinischen Studien geworden. Diese Debatte hat wiederum zur Entstehung neuer Forschungsprojekte geführt, die sich mit potenziellen Affinitäten und Unterschieden zwischen der »New Perspective on Paul « und der östlich-orthodoxen Paulusinterpretation befassen. Der vorliegende Sammelband nimmt daher die Diskussion zwischen »östlich-orthodoxer «, »neuer « und »alter« Perspektive auf Paulus auf und sucht, sie weiterzuentwickeln. Ziel dieses Bandes ist es, den Dialog zwischen der »New Perspective« und der östlich-orthodoxen Rezeption von Paulus auf einer exegetischen Basis anzuregen. Aus diesem Grund konzentrieren sich die Beiträge auf Texte, die in der Debatte über Partizipation, Rechtfertigung und Bekehrung bei Paulus eine entscheidende Rolle spielen. Drei Beiträge am Ende des Bandes bieten alternative Lesarten von Paulus, die über die Argumente der »alten« und »neuen«Perspektiven auf Paulus hinausgehen.

\section{Inhaltsübersicht}

Introduction

\section{Part I: The Real Contexts}

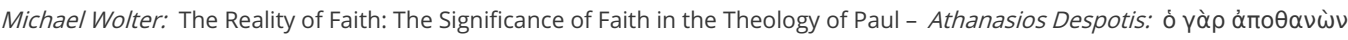

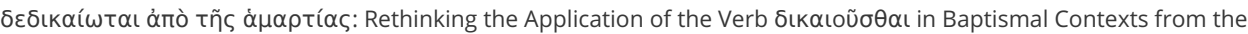
Perspective of Rom 6:7 - Jacobus (Kobus) Kok/ John Anthony Dunne: Participation in Christ and Missional Dynamics in Galatians

\section{Part II: Orthodox Readings of the Relevant Pauline Texts}

Konstantinos Nikolakopoulos: Paulus über »Gerechtigkeit« und »Rechtfertigung«. Exegetische Perspektiven unter Berücksichtigung von 1 Kor. 1,30 - Stelian Tofana: »Treasure in earthen vessels...« (2 Cor 4:7-11) - Edith Humphrey: Becoming the Righteousness of God: The Potency of the New Creation in the World (2 Cor 5:16-21) - Vasile Mihoc: Galatians 2:15-21: A Commentary Challenging the »New Perspective on Paul« - Sotirios Despotis: Eine östlich-orthodoxe Lektüre von Gal. 3,6-9.23-29 - Jack Khalil: An Interpretation of Rom 3:21-26 within Its Proper Context - Michael Azar: The Law and New Life in Rom 7:1-6: Eastern-Western Dialogue and Romans - James Buchanan Wallace: Identities at Risk: The »New Perspective on Paul« and Eastern Orthodox Interpretation of Rom 8:14-17; 28-30

Part III: Beyond Old and New, Beyond East and West

MichaelJ. Gorman: Reading Gal 2:15-21 Theologically Beyond Old and New, Beyond West and East - Athanasios Despotis: Beyond Theological Arguments. The Ethics of Love and Coming to Faith in Paul - Rikard Roitto: Paul's Theological Language of Salvation as Social and Embodied Cognition

Athanasios Despotis Born 1979; studied Theology and Classical Philology at the University of Athens; 2006 PhD; 2012 Habilitation at the University of Bonn; since 2014 Heisenberg Fellowship at the University of Bonn.

Jetzt bestellen:

https://mohrsiebeck.com/buch/participation-justification-and-conversion-9783161554537?no_cache=1

order@mohrsiebeck.com

Telefon: +49 (0)7071-923-17

Telefax: +49 (0)7071-51104 